\title{
THE RELATION OF ALCOHOL TO PHYSICAL DETERIORATION AND NATIONAL EFFICIENCY.*
}

\author{
BY W. MCADAM ECGLES, M.S., F.R.G.S.
}

IN July, 1904, the Inter-Departmental Committee on Physical Deterioration presented their report.

They had been instructed to make an enquiry into the allegations concerning the deterioration of certain classes of the population, as shown by the large percentage of rejections, for physical reasons, of recruits for the army, and by other evidence.

Particular and ascertained facts concerning the relation of alcohol to physical deterioration were presented to this InterDepartmental Committee by Dr. Robert Jones and myself at the request of an influential committee of medical practitioners.

The day on which extracts from the Report appeared in the Times, I had the honour of presiding in this Town Hall at a breakfast given by the National Temperance League to the members of the British Medical Association, at that time holding their annual meeting in this city under the presidency of your revered citizen, Dr. William Collier. Since that occasion very considerable interest has been taken by the public regarding the relation of Alcohol to Physical Deterioration.

When, therefore, I was asked by the trustees of the Lees and Raper Memorial Lectureship to deliver the eighth lecture, I felt that it would be fitting to do so in Oxford, before Members of the University as well as the general public.

* The Eighth Lees and Raper Memorial Lecture, delivered in the Town Hall, Oxford, on Tuesday, February 4, 1908, under the presidency of Professor William Osler, F.R.S., M.D., D.Se., Regius Professor of Medicine in the University of Oxford. Published in this journal by the special permission of the Lees and Raper Memorial Trustees. 


\section{THE APPEARANCE OF LIFE.}

A small mass of protoplasm appeared upon this earth, we know not when or where. It was living matter, and endued with unknown potentialities. It lived, it moved, it had its being. Around it was its environment; above it was the atmosphere, containing oxygen, a necessity for its very existence; beneath it was water, capable of bearing it upon its surface or sheltering it in its depths.

Endowed with powers, mysterious even to-day, this speck of protoplasm was capable of absorbing and assimilating food; capable also of rejecting noxious material, and thus avoiding danger, if any such existed. Moreover, it reproduced its kind, and so the earth was peopled.

In its early days, this particle of living matter would seem to have had every portion of its surroundings in harmony with itself. All around ministered to its wants; none was a foe, all were friends.

Soon, however, we know not why, antagonistic forces began to act upon it. The water in which it floated chanced to contain that which acted harmfully upon its substance.

\section{THE STRUGGLE FOR EXISTENCE.}

Thus commenced a struggle-the struggle for existence. The opposing forces were-the living matter and the poison.

It is significant that every human individual begins existence as a single and simple cell, and this cell has to fight for its existence even from its earliest days.

Every adult human being has circulating in the blood a large number of cells similar to the original single cells. These carry on a warfare against enemies that may gain access to the blood of the individual, a warfare alike full of interest and danger-the warfare between the phagocyte and the bacterium.

Practically every particle of the human body-the brain, the liver, bone, or muscle-is made up of specially constructed cells, which in their turn have been derived from the original cell.

The warfare of the animal cell against external poisons is one of the unending activities of life. That this conflict may in a 
sense be healthy up to a certain degree is undoubtedly true, and this fact should be more widely admitted and recognized.

Such combat may strengthen the individual cell in the same way that muscular activity will increase the size and add to the power of the biceps.

But directly the poison is sufficiently strong, it may seriously affect the actual living element of the cell, and deterioration, or even death, must inevitably occur.

If the effect of any given poison is constantly repeated, the structural changes in the cell will be the more marked, and will tend to become permanent.

The number of substances which can thus deleteriously act upon the animal cell is very great.

\section{ALCOHOL.}

Among them is alcohol. This term is used for a series of chemical bodies having a similar composition and similar properties.

The origin and application of the word is a matter of some little interest. At first it was used to designate any particularly fine powder which could be employed to stain the eyelids, then to designate any fine impalpable powder obtained by trituration or grinding, or a like powder obtained by sublimation. Afterwards by extension it was applied to fluids obtained by distillation, and later to that class of compounds which has just been indicated.

Alcohol is very widely distributed in Nature, and is, in fact, actually produced in the animal economy, but only in such quantities as may be deemed negligible. It is largely obtained artificially by man for a variety of purposes, but chiefly to form one of the constituents of the many beverages habitually partaken of by him.

Hence it comes about that alcohol in a more or less dilute condition gains contact with all the cells of the bodies of the greater number of adult individuals in the nation. Hence it also follows that, if it acts as a poison, it may cause serious and often irremediable deterioration. 


\section{DETERIORATION.}

By deterioration is meant the process of growing or making worse.

My proposition, therefore, is that alcohol acts on the human living cell as a poison, using the word in its true physiological sense, and tends to produce a deterioration of that cell, and consequently of the individual as a whole, and, by extension, deterioration of the race.

I shall endeavour to prove this proposition by scientific demonstration, and then point out some of the means which may be adopted to counteract the deterioration which appears to be increasing in our midst, and sapping the efficiency of the nation. Every one is agreed, even the consumer of them, that large doses of alcohol play havoc with the moral, mental, and physical constitution of both men and women, and even of children, and I need therefore say nothing from this point of view. But it is only in quite recent years that the fact is being forced upon the scientific mind, that even small quantities of alcohol habitually taken may do serious harm.

\section{HEREDITY.}

And, further, it is even as yet hardly recognized that the very germ or sperm from which we have our being may be harmfully affected by alcohol, and even from comparatively small doses.

Alcohol taken into the stomach can be demonstrated in the testicle or ovary within a few minutes, and, like any other poison, may injure the sperm or the germ element therein contained. As a result of this intoxication of the primary elements, children may be conceived and born who become idiots, epileptics, or feeble-minded. Therefore it comes about that even before conception a fault may be present. Although this fact may not as yet, from want of sufficient investigation, rest upon thoroughly attested evidence, yet there is absolutely no doubt that the growing and developing embryo is liable to much injury from contact with alcohol before birth.

Experiments almost numberless have been conducted on these lines, and the results have been so very markedly uniform that they can hardly be doubted to be other than facts. 


\section{EARLY DEVELOPMENT.}

Take the example of the action of alcohol upon frogs' spawn, an experiment that every one can repeat, if he cares to, this coming spring. It should be noted that in actual composition and construction the eggs of the frog differ but little, even when observed by the microscope, from those of the human race.

Every experiment in this line of investigation must be checked by a control experiment, a condition which is too often lost sight of by investigators.

The experiment and the control are carried out as follows: A portion of frogs' spawn is placed in water in a watch-glass, the water being ordinary tap-water, and another portion of spawn from the same batch is placed in tap-water containing 2 per cent. of alcohol in a similar watch-8lass. ( 2 per cent. of alcohol is about 10 drops of absolute alcohol to 1 ounce of water.)

Both are placed under otherwise favourable conditions for development, but the result in the two watch-glasses is very different. It is normal in that one in which tap-water alone was used. But where diluted alcohol is in contact with the spawn, many eggs fail altogether to develop, and the tadpoles which are hatched are undersized and feeble. Subsequently they fail to grow as large as they should, do not so quickly develop gill-slits, and exhibit only feeble movements.

A precisely similar want of development is seen in the higher grades of animal life. It has been repeatedly shown that the action of alcohol vapour upon the esgs of a hen during incubation is to cause abnormal development of the chick, both from the point of view of size and of structure. Experiments upon young rabbits and puppies have given similar results. If some of the litter are allowed to have food which has been treated with small quantities of alcohol, these will be found to develop but feebly; alcohol has had a deleterious effect on the development of their weight and length of body.

And the young of the human animal are no exception to the rule; for let alcohol, even in small quantities, come in contact with the growing cells of the human infant, and there is a chance-nay, a probability - that irreparable harm will be done. 
TOXINS.

It is a momentous fact that the cells of the individual may be damaged even before the child is born. Poisons-toxins-circulating in the mother's blood can pass, and often do pass, into the organism of the child. Alcohol is one of the poisons which may so invade the developing infant. We know but little as yet of the laws of heredity, but we do know that disease may be impressed upon the child before birth, and that a child may carry such an impress in a latent manner for long after birth, the resulting handicap to its welfare in the world only becoming apparent in many instances when some strain is thrown upon it. Then it is that the inherent defect shows its existence, and the individual evinces that crave for alcohol which the normal brain might have been able to withstand. It is thus that a vicious circle of the most serious import may be brought into existence. A father or a mother, or both parents, are given to excessive indulgence in alcoholic beverages. Their offspring are affected, it may be quite insidiously, and they in their turn produce degenerates one degree worse than themselves.

\section{ACTION OF ALCOHOL ON GROWING TISSUES.}

But a child of alcoholic parents may escape contamination before birth, only to be caught by the foe very soon after it enters the world. A nursing mother who gives way to drink generally feeds her child with milk which is poor in quality and deficient in quantity. The amount of milk is not increased by alcoholic beverages, and there is no such thing as "nourishing stout of the greatest value to nursing mothers." Frequently the milk contains a very appreciable amount of the drug which the mother has been imbibing, for alcohol can be readily traced in the mother's milk within twenty minutes of its ingestion into her stomach, and it may be detected in it for as long as eight hours after a large dose.

Dilute alcohol thus passed into the system of the child invades every part of its being, and has a particularly harmful effect upon the growing cells of its developing brain. It is in this manner possible to pave the way for many degenerative lesions which are manifest in later years. Numerous cases have been reported in which infants at the breast have been the subjects of both acute and chronic alcoholic poisoning, the results of which have remained as permanent defects in the individual. 
It is on account of these well-known facts that many hospitals, in the hints which they issue to mothers on the rearing of infants, lay stress on the recommendation that alcohol should be avoided, a recommendation which is very different from the ordinarily accepted idea in the public mind.

It is not only, however, that the infant may receive alcohol mixed with the natural food derived from its mother, but it is by no means unusual for alcohol to be administered to it apart from maternal milk. It is not an uncommon sight to see quite young children carried into the public-house, and there treated to beer or even spirits. The child makes a wry face over its dose-evidence that alcohol is not a fluid appreciated by the untutored palate - a fact which ought to indicate to any but the most ignorant that its proper use is that of a drug rather than a beverage.

This administration of alcohol is made, I verily believe, as the result of maternal ignorance in most instances-an ignorance which does not redound to the credit- of the educationalists of our land. When a mother was recently remonstrated with for thus exposing her infant to danger, she was furious with indignation, and her caustic remark was, "Who are you talking to, young man-to me as buried six ?"

\section{ALCOHOLIC MOTHERS.}

Women who are public-house frequenters are not only bad nurses, but they are also bad mothers. How is it possible for a woman to be a mother in the truest sense when she is wretchedly fed because so large a proportion of the weekly earnings go in drink, when she is thinly clothed because the pawnshop swallows up any decent garment which may have been dearly purchased, and when she is so utterly careless of all her ways because her intellect and finer feelings are blunted by alcohol? And yet this is the condition of thousands of so-called mothers in our large cities and towns. Statistics carefully compiled show that the average spent on drink per week by each working-class family in the land is no less than six shillings. If this amount goes on what, to say the least, is not a necessity, how can there be enough left to provide adequate food, housing, and clothing for the parents and the children? It is an established fact that many thousands of families in London have not an income large enough to obtain for each member even that amount of food

vol. $v$. 
provided for the ordinary pauper inmate of the workhouse, and how then can it be justifiable for the family to spend nearly one shilling a day on alcoholic beverages?

\section{OTHER FACTORS.}

I am perfectly willing to admit that poverty, bad housing, and all the accompaniments of a wretched environment, lend their share in the production of the deterioration which exists; but $I$ am convinced by my own observations, and by those of many another student of social economics, that at least 50 per cent. of the instances of child deterioration is due directly or indirectly to habitual intemperance in one or both parents. The statistics recently published concerning the height and weight of school children both in Glasgow and Edinburgh go far to prove the fact that life in one room means want of growth ; and a single livingroom often means rent-money spent on drink.

Investigation into the home environment of 72,857 schoolchildren in Glasgow brought out some startling facts. Taking the children of all ages from five to eighteen, the average weight and height, classified according to the number of rooms, was found to be as follows :

\begin{tabular}{|c|c|c|c|c|c|c|c|c|}
\hline $\begin{array}{c}\text { Rooms. } \\
1\end{array}$ & - & - & $\begin{array}{r}\mathrm{He} \\
46^{\circ} 6\end{array}$ & $\begin{array}{l}\text { Boy } \\
\text { hht. } \\
\text { ches }\end{array}$ & - & - & $\begin{array}{c}W \\
52 \cdot 6\end{array}$ & $\begin{array}{l}\text { bt. } \\
\text { unds. }\end{array}$ \\
\hline 2 & - & - & $48 \cdot 1$ & , & - & . & $56 \cdot 1$ & , \\
\hline 3 & - & - & $50^{\circ} 0$ & , & - & & 60.6 & ", \\
\hline 4 & - & - & $51 \cdot 3$ & , & 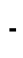 & & $64 \cdot 3$ & " \\
\hline $\begin{array}{c}\text { Rooms. } \\
1\end{array}$ & - & - & $\begin{array}{r}\text { He } \\
46^{\circ} 6\end{array}$ & $\begin{array}{l}\text { Girl } \\
\text { hht. } \\
\text { ches }\end{array}$ & - & & $\begin{array}{r}W \\
51 \cdot 5\end{array}$ & $\begin{array}{l}\text { ht. } \\
\text { unds. }\end{array}$ \\
\hline 2 & - & - & $47 \cdot 8$ & , & - & & 54.8 & ,, \\
\hline 3 & - & - & 49.6 & ,, & - & & $59 \cdot 4$ & ," \\
\hline 4 & - & - & $51 \cdot 6$ & , & - & & $65 \cdot 5$ & , \\
\hline
\end{tabular}

As the report states: "It cannot be an accident that boys from one-roomed homes should be 11.7 pounds lighter on an average than boys from four-roomed homes, and 4.7 inches smaller. Neither is it an accident that girls from one-roomed homes are on the average 14 pounds lighter and 5.3 inches shorter than giris from four-roomed houses. The connexion between drink and the one room is obvious." 
The chances of a poor boy in Edinburgh, in the struggle for existence, are assessed eloquently enough in the following table. In the middle classes he starts at thirteen with 84 pounds of clean and healthy bone and muscle ; in the slums he must do his best with 71, and an even chance that one or all of his senses are defective. Even more significant, however, are the averages which show the comparative development of the slum boy, according as his parents attempt to bring him up in one, two, or three rooms :

$$
\text { At Five Years of Age. }
$$

\begin{tabular}{|c|c|c|c|c|c|c|c|}
\hline $\begin{array}{c}\text { Rooms. } \\
1\end{array}$ & - & $\begin{array}{r}\mathbf{H} \\
39^{\circ} 9\end{array}$ & $\begin{array}{l}\text { ht. } \\
\text { ches }\end{array}$ & - & 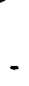 & $34^{-6}$ & $\begin{array}{l}\text { ht. } \\
\text { unds. }\end{array}$ \\
\hline 2 & . & $40 \cdot 2$ & , & - & - & $37 \cdot 5$ & ," \\
\hline 3 & . & 41.9 & , & - & - & $42 \cdot 0$ & , \\
\hline 4 & 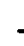 & $42 \cdot 0$ & ," & - & - & $45 \cdot 5$ & , \\
\hline
\end{tabular}

\section{At Thirteen Years of Age.}

\begin{tabular}{|c|c|c|c|c|c|c|c|c|}
\hline $\begin{array}{c}\text { Rooms. } \\
1\end{array}$ & - & - & \multicolumn{2}{|c|}{$\begin{array}{l}\text { Height. } \\
52 \cdot 9 \text { inches }\end{array}$} & - & - & \multicolumn{2}{|c|}{$\begin{array}{l}\text { Weight. } \\
61.5 \text { pounds. }\end{array}$} \\
\hline 2 & - & - & $53 \cdot 9$ & , & - & - & 69.9 & , \\
\hline 3 & - & - & $54 \cdot 7$ & , & - & - & $75 \cdot 8$ & , \\
\hline 4 & - & - & $55 \cdot 8$ & ," & - & - & $76 \cdot 7$ & ," \\
\hline
\end{tabular}

\section{CONCLUSION OF INTER-DEPARTMENTAL COMMITTEE.}

So impressed were the members of the Inter-Departmental Committee on Physical Deterioration with the evidence laid before them concerning the relationship of alcohol to deterioration that they place the consumption of drink next to urbanization as a causative factor.

Their emphatic words--" The Committee are convinced that the abuse of alcoholic stimulants is a most potent and deadly agent of physical deterioration "-should be pondered over by all who have the welfare of the nation at heart.

And this abuse of stimulants commences to act even before the birth of the child, continues its effects in infancy, and is often perpetuated in youth and adult life. How, therefore, can it be otherwise than debility in the earliest days, stunted growth before maturity, and deterioration and mental inefficiency at the time when the nation demands the finest and most productive output from those who should be its grandest asset? 


\section{ACTION OF ALCOHOL ON ADULT TISSUES.}

So far as the effect of alcohol indirectly and directly upon growing tissues has been discussed, all the facts adduced point to its being a strong factor in the production of physical deterioration.

It is necessary now to review the action of alcohol upon the tissues of the adult. Here, again, it is only needful to make a passing allusion to the effects of large doses of the drug upon the physical and mental constitution of the individual. The inebriate, as a rule, carries his infirmity written upon his face, or dictates the same by his words and actions. He is unstable in thought and precision, and his muscular as well as his mental powers soon become inefficient.

It is wise to reiterate some facts which are not often given their due significance.

\section{ALCOHOL A SELECTIVE POISON.}

Alcohol is a selective poison, and acts very differently on different individuals and upon different tissues in the same individual.

There are many poisons which act in a similar manner, some of them being well-known drugs, and others less-known products of the activity of bacteria or micro-organisms. Strychnine is an example of the former, and this drug has a peculiarly selective action towards the central nervous system and the spinal cord in particular. The toxin produced by the "drum-stick" bacillus of tetanus or lockjaw illustrates the second, for again the spinal cord is the tissue chiefly affected. Alcohol, on the other hand, is a poison which has a distinctive action upon the cells of the blood and upon the cells of the vessels through which the blood circulates.

Every part of the body is dependent upon the blood for its nourishment, and any factor which interferes with the proper composition or circulation of this fluid is a factor in the production of imperfect nutrition and consequent deterioration. There are two ways in which alcohol plays havoc with the tissues of the adult. The blood itself by carrying the poison is rendered abnormal ; its constituent cells cannot do their proper work-in fact, they are intoxicated. 
The amceba, that beautiful unicellular animal, is profoundly affected by even small doses of alcohol, actually by one drop of alcohol in one thousand drops of normal saline solution, the fluid in which it is best at home. By alcohol it is irritated-"stimulated," if you like-just at first, but quickly numbed, then paralyzed, and finally killed.

The white blood-cell is practically an amœba. Alcohol taken into the stomach is rapidly absorbed through the mucous membrane into the bloodvessels. There it comes into contact with the white corpuscles of the blood, and they likewise are irritated, numbed, paralyzed, and even killed. Thus these cells, which should be alert, discriminating, and efficient, like any welltrained constable, become lazy, inert, and altogether inefficient when any undesirables in the shape of bacteria cause " riot in the veins."

\section{ACTION OF ALCOHOL ON THE ARTERIES.}

But, in addition to the constituents of the circulating fluid being thus interfered with, the walls of the tubes through which it passes are liable to be damaged. A condition which is known as arterio-sclerosis is brought about. This term indicates a hardening and thickening of the walls of an artery.

In the healthy state an artery is an elastic tube which, by its very elasticity, forces the blood, pumped into it by the heart, to the remotest parts of the body. Even if the heart "beat" normally, blood would not, as a rule, reach the toes without the further propelling power of the elastic arterial walls.

Given then arteries which have lost their natural elasticity, and many parts of the body will in consequence suffer from malnutrition.

Alcohol produces this hardening effect upon the arteries. In fact, some authorities believe that alcohol shares with one other toxin the evil repute of being the most potent cause of arteriosclerosis. It does not, moreover, require large quantities of alcohol to produce this effect; even so-called " moderate" doses, if sufficiently long continued, will cause the arterial wall to become so changed that the vessel will be a rigid, and often actually a brittle, tube. Added to this, there is a serious resultant effect upon the heart itself. This organ, because of the loss of the help normally given to it by the elasticity of the bloodvessels, has now an increased amount of work to do in 
endeavouring to urge the life-preserving fluid to every part of the system. Sooner or later the heart will be unable to stand this extra strain, and it will give way under it with dire results. "A man is as old as his arteries" is a witty saying, but none the less is it a true one. If the arteries in childhood are elastic, supple, and soft, those of an old man are liable to be hard, firm, and rigid. They have deteriorated; they have begun to wear out, or to become "furred" like a water-pipe. If a young man takes alcohol, and it has this deteriorating effect upon his arteries, an effect which is often very insidious and almost unrecognizable in its earlier stages, he will become prematurely old : he will deteriorate before his time, and the nation will lose his efficient service before he has given his proper quota to the nation's work. He will become, in fact, as old as his " aged" arteries are, and he has thereby to all intents defrauded society.

While, then, alcohol may act directly upon the elastic tissue of the arterial wall, this is not all, for it may also act indirectly. Alcohol retards the excretion of toxins and other poisons from the blood. It is a fact worthy of notice that muscular activity causes the formation of a peculiar waste product termed " hypoxanthin." This has to be eliminated as quickly as possible if the individual wishes to keep fit. It is absorbed by the lymphatics and passed into the blood, by it carried to the kidneys, and by them excreted. It is a definite poison, and like alcohol tends to produce arterio-sclerosis.

Alcohol markedly diminishes the excretory power of the organs which cleanse the blood of its impurities. Alcohol thus prevents the rapid elimination of hypoxanthin, with the result that the blood becomes surcharged with the poison. In this fact lies the chief reason why all in strict training advisedly eschew the use of alcoholic beverages.

Hence it can be clearly seen that the two deteriorating substances may be acting together, the one being as it were the complement of the other, with the consequence that the alteration in the arterial wall is doubled in its severity. Over-eating of animal food introduces into the blood an excess of a similar product to that known as bypoxanthin, and where this over-indulgence in meat diet is associated with an habitual use of alcohol, the double force will again be at work.

If, therefore, anyone wishes to keep young and fit, let him above all things be moderate in his diet, and avoid all forms 


\section{The British Journal of Inebriety}

of alcohol. Many other toxins present in certain diseases are much more potent when alcohol is also present, or when alcohol has already diminished the resisting power of the organism. This is particularly manifest when the toxin of influenza is circulating in the blood.

\section{INSURANCE STATISTICS.}

The wearing out of the arterial system, through even the moderate use of alcohol, is one of the greatest risks to the life insurance office, and the medical examiner has ever to be on his guard against its existence.

Some proposers bear evidence of the condition stamped upon their faces, or written by the hardness of their vessels. In others, again, it is only by a very close and careful examination that the fact can be demonstrated.

A few years ago a well-known life office issued a circular, offering to insure abstainers of two years' standing and upwards at a slightly reduced premium. A leading financial paper, commenting on this, said: "A battle has long raged round the figures of those offices which keep their men in separate sections, and always show a higher bonus to the longer-lived abstinent. Strenuous efforts have been made to minimize these important statistics, and it is likely enough that they do not mean quite all that has been claimed for them; but when we see a first-rate company offering a direct and immediate cash bonus to abstainers, it looks very like as if the case had been proved."

An extremely interesting demonstration has been made by those insurance offices which possess two carefully separated sections, the one for abstainers and the other for non-abstainers from alcohol.

I happen to be the chief medical officer to one such company, and here are the facts of the case :

The office was founded in 1864 , over forty years ago, and from the first it had these two sections. The "lives" in the nonabstaining section have always been "good"; in other words, even the non-abstainers are derived from a class which does not hurry itself to its grave by unnatural habits of life.

The founders of this office were from motives of sound business anxious to make the general or non-abstainers' section thoroughly high-class. They gave strict injunctions to their agents and 
medical examiners that only the best of proposals should be sought for and accepted. So strict has been the investigation before approval that only eighty out of every hundred deaths that were expected by a rigid standard have been realized. This is even better than the directors hoped for, and is a matter of sincere congratulation, not only to the longer-lived, but also to the society. The founders were even wiser than the result of the non-abstaining section would show. Their establishment of a section for those who were total abstainers from alcohol, and were at the same time living under similar conditions as those in the non-abstaining section, has proved still more satisfactory. In this section there were only fifty-four deaths out of every hundred expected, and the significance of this fact is so great that it cannot be overlooked.

I introduce here an instructive table, which still further confirms these facts :

Mortality Experience of Four Companies (Ordinary Whole-Life Policies).

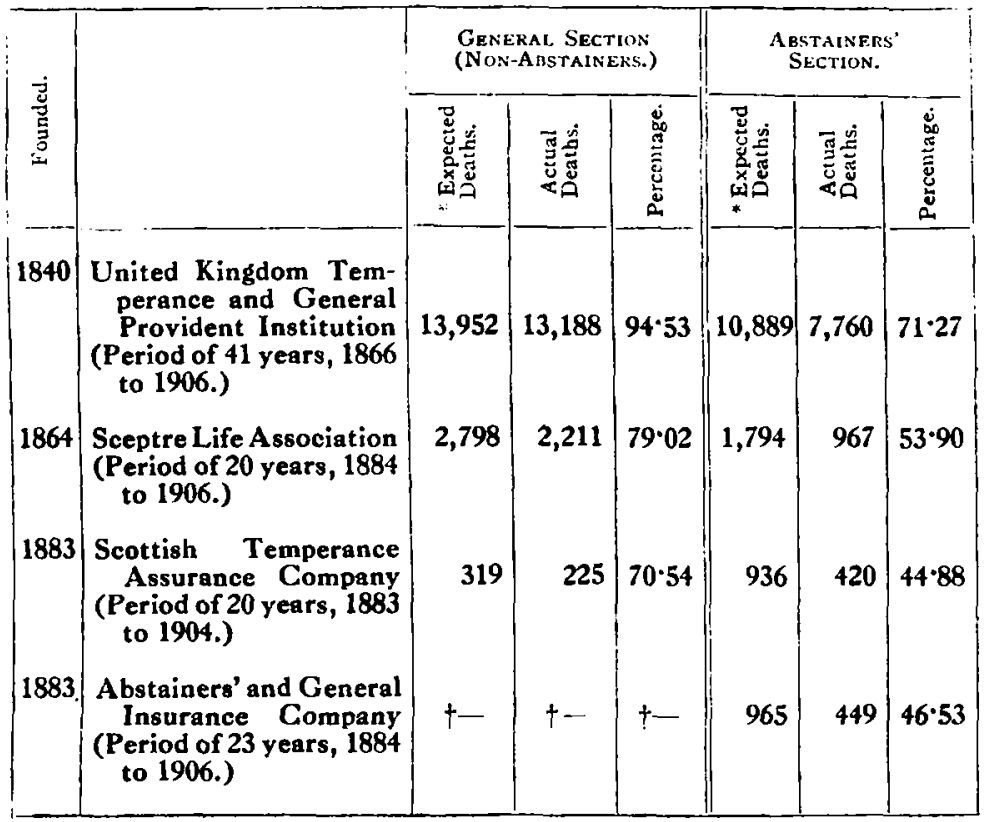

- Expected Deaths under the H/m Table of the Institute of Actuaries. † No figures published. 


\section{REMEDIES.}

Having endeavoured to conclusively prove that there is a marked relationship between the alcohol drunk in ordinary alcoholic beverages and deterioration of the tissues of the body, there yet remains for me to show how the deleterious effect of alcohol on the physical welfare of the nation may be minimized or abolished.

It is proverbial that "Prevention is better than cure."

When once deterioration has made a marked impression on the individual, there is but little hope that the result can be eradicated. It is impossible to introduce new arteries, to regenerate nervous tissue, to restore mental balance, and to regain complete efficiency.

There is much said at the present day concerning the necessity of a living wage, and the inadequacy of the amount paid to the unskilled worker to provide him and his family with the bare needs of life. The fact is, however, not so much that higher wages should be paid to the unskilled worker, but that there should be no such person as one who must rank as unskilled or inefficient. Even the navvy ought to be skilled in his own particular line of occupation, and ought to be efficient in it. If he cannot properly use his spade, whether from want of knowledge as to how to manipulate it, or from lack of muscular power to drive it home, ought he to receive the same rate of wages as his skilled mate? His ignorance is the fault, in most instances, of the State in not seeing that he is provided with that training which makes for efficiency. His lack of muscular power is all too often the result of poisoning by the drinking of alcoholic beverages.

The want of efficiency produced by alcohol is well known by a series of experiments, arranged in Sweden, with the object of ascertaining the influence of alcohol upon accuracy in marksmanship. None of the men experimented upon were abstainers. Three corporals and three privates were chosen for the purpose. In the first series of experiments no alcohol was given. In the next it was provided, and in the third it was again withdrawn. Spirits and beer were alternately tried. The result of these experiments indicated, without a single exception, a reduction of the accuracy of aim as a result of the alcohol consumed. Yet all the men, after receiving their allotted portion of alcoholic 
drink, had declared that they felt far more capable-but found themselves deceived.

Many doubtless are inefficient because of congenital defect. They are born of parents who were themselves degenerate, are nurtured in surroundings which produce further deterioration, and continue to poison themselves with a drug which makes for greater changes in the tissues and greater inefficiency.

\section{PREVENTIVE MEASURES.}

Therefore prophylaxis, or prevention, is all-important - the only true and scientific manner by which the real remedy for the state of things is to be found.

Start with the children, go on with the children, finish with the children, and in the course of even one generation a decided public opinion will be formed.

Then, and to my mind only then, will Acts of Parliaments have the far-reaching effect for which they are framed.

Here are seven suggestions, not new by any means, but suggestions which have a very practical bearing on the question of prevention :

Educate the mothers and fathers.

Prohibit the entrance of children into public-houses.

Feed the children.

Teach the children.

Limit the opportunities for adults to obtain liquor.

Provide healthy recreation.

Promote research and publish results.

I can only very briefly touch upon these propositions in the time at my disposal. Some may, perhaps, affirm that they are idealistic and practically unworkable, but to these objectors I would humbly say-try them in the right manner and see the results.

\section{EDUCATE THE MOTHERS AND FATHERS.}

I have purposely put this first. What is so much needed is a sound practical education of the parents of the children, particularly of the young men and young women who are on the threshold of life. How is this education to be accomplished? 


\section{The British Journal of Inebriety}

That of the women comes first. A good mother produces and trains efficient sons. The young women must be taught the elements of child-rearing, of good cooking, and of household management on a small income. There is no grander national work than this for the ladies of the land-provided always that they know the elements themselves. The numerous borough and parochial health societies which are being established are all in the right direction, and cannot fail to do good.

With regard to the men, it should be the aim of every young men's guild and debating society to introduce the question of alcohol in relation to the welfare of the nation at least once in every year, and let the matter be frankly and fairly debated and voted upon.

Then, for both men and women, a vast amount of instruction can be given on the subject by the placarding of hoardings with posters officially issued by the Health Committees of the Municipal Authorities. Since the appearance of the InterDepartmental Committee's Report this method of education has been extensively used; but it should be repeated year by year, and more widely extended. It would be politic if those interested in the question, whether themselves abstainers or not, would see that the City and Borough Councils were provided with a special sum for this purpose, so that no one might say that public money was being illegally used.

I believe in the Municipal Authorities themselves doing the work officially, for it comes with so much more force than if from private enterprise. Surely it is the proper work of the municipality, for the health of the people is at least as important as the lighting of the streets. If the authorities issue notices with regard to the spread and prevention of consumption, they have as much right and responsibility to issue others on the relation of alcohol to physical deterioration and disease. Even the proprietor of the public-house has no hesitation in exhibiting notices concerning consumption, and possibly ere long he may become public-spirited enough to do so concerning the deleterious effects of alcoholic beverages.

\section{PROHIBIT THE ENTRANCE OF CHILDREN INTO PUBLIC- HOUSES.}

The recent disclosure of the truly awful effects of the presence of children in public-houses calls for immediate legislation in the 
direction of at least this amount of prohibition. It would do much to keep the children free from actually imbibing alcohol, and much to maintain the sobriety of the mothers.

\section{FEED THE CHILDREN.}

It is useless to prevent the child from drinking alcohol, if at the same time he does not receive sufficient food for the proper growth of the body. I believe implicitly that the hungry child must be fed, and fed from its earliest days. If during school years it is found to be underfed by its parents, it should be permissible for official inquiries to be made by responsible officials. When by these investigations it is found that the fathers are earning wages, and squander even a portion of them upon drink, a means should be found whereby a corresponding part of this weekly wage should be annexed for the feeding of the child under the supervision of the Educational Authority, and not at the expense of the charitable or the rate-payer.

If the fathers are workless, the Municipal Authorities should do all in their power to provide or discover work, with a scheme whereby part of the money earned is, where necessary, diverted for the feeding of the children.

The children must be fed, and, until a sounder state of affairs comes about, the educational committees will be forced to feed them; for to attempt to teach hungry and ill-nourished children is sheer folly.

\section{TEACH THE CHILDREN.}

Herein, I am sure, lies the secret of future betterment.

Teachers are wanted-skilled teachers, with an aptitude for teaching. Teachers are wanted who themselves have been taught the principles of hygiene and temperance, and who can impart their knowledge simply and graphically.

How is the future mother of the child to be taught the manner in which she should rear that child? Why, surely, by teaching her from her youngest days the right methods, with an example before her in the doll and the doll's house. Cleanliness, tidiness, and the value of fresh air, sensible cooking, and rational food and drink, can be inculcated in a pleasant and instructive manner to even the very young. If the child is taught how to keep its doll clean, it will unconsciously imitate the same good manner 
in its own being and clothing. So also if the young mind is early made to learn that milk should be the chief component of its diet, and that other beverages are not desirable for children, it will at least, when it reaches the years of discretion, not have had its mind so biased that it cannot choose the good from the bad.

Teach the children throughout the land the elements of hygiene and temperance. I am more than thankful that the teachers in the elementary schools of our country are so fully alive to the value and importance of such instruction, and are giving it in a manner which does them infinite credit. They are doing a magnificent national work, and one which is not sufficiently recognized by the public.

If this teaching is thoroughly and practically given, there is no reason why in a succeeding generation a public opinion shall not have been created which will carry with it all needed legislative reform in the matter of liquor control.

\section{LIMIT THE OPPORTUNITIES FOR ADULTS TO OBTAIN LIQUOR.}

England is not ready for total prohibition. It is essential that the majority of the nation should be carried with every advance in stemming the tide of alcoholic poisoning. The majority of the nation still consider that a moderate amount of alcohol is a good thing, but all who think admit that much is bad. It is the facility with which alcoholic beverages can be obtained that in many instances causes the downfall of so many. Other poisons, not so commonly used, are much more severely restricted in their sale, and no one considers that the liberty of the subject is thereby threatened. If morphine were on sale as readily as its fellow-poison, alcohol, I do not think that politicians would take long to put it under even more stringent safeguards than it is at the present. I am not going to suggest that every one who desires to imbibe spirits or any drink containing alcohol should be forced to sign a paper before he could obtain them; nevertheless, I will say that I do not think we are acting in the truest interests of the nation or the individual when we allow a publichouse in many of our cities and towns to be so close to the dwelling-house that it allures the working man to enter it rather than return to his own dwelling; and certainly facilities should be given to the local inhabitants to object effectively to such 
houses remaining in their midst. Nor do I think that the grocer's licence has been such as has tended to the sobriety of the women of our land.

The subject of the limitation of supply is confessedly a difficult one, and will only be solved, in my opinion, by improved habits and by the people themselves being empowered to indicate by vote that they are not desirous of retaining such over-abundant facilities.

\section{PROVIDE HEALTHY RECREATION.}

If the public-house is the only means whereby the artisan can obtain that social interchange and recreation which is his right, then, if it is to lose its hold or to be abolished, something must take its place. This is felt by all, and every student of social economics must give the matter most earnest consideration. If money is not spent in useless drink, it will be ready for other outgoings. Extra rent can be afforded, and thus a taste for better things will arise. More money will be available for reasonable recreation. The better-class concert, the rifle range, the boys' clubs, the well-conducted working men's clubs, and many other means of recreation, will then meet with better patronage than they do at present. But above all these, let the women of the land make the home cheerful and happy for the husband and the brother, and let not that grand heritage of old England-home and hearth-disappear; for nothing better can take its place.

\section{PROMOTE RESEARCH AND PUBLISH RESULTS.}

There can be little doubt that the wider the diffusion of sound knowledge, the more rapid will be the trend of public opinion in the right way. It is a happy augury that at the present day some of our temperance societies are promoting research along sound and carefully-thought-out lines; but it would be far more forcible if the Universities themselves were able to promote these particular investigations under their own auspices. Surely, a matter of such national importance and widespread interest should find a response from the seats of learning in a more definite and practical form than it has hitherto done.

We are in the days of rapid advance, and while $I$ for one should be sorry to see our Universities-the older ones, at least -giving up subjects of learning for which they have been for centuries rightly famous, yet they must be abreast of the times, 


\section{The British Journal of Inebriety}

and the consideration in greater detail of problems of national and international importance should have a serious place in their programme.

The subject of alcohol has so many sides to it--social, economical, political, medical, and religious-that it is well worthy of a close study by all those who in after-life will have the affairs of the nation on their shoulders.

The University should not only promote research, but it should also publish, with its weighty authority, the results of such study and investigation. By doing so it will add greatly to our knowledge, and will hasten the day when our nation will no longer suffer the mental, moral, and physical deterioration of its individuals as the outcome of poisoning by alcohol, but will secure the universal development of that national efficiency which has always been our boast.

I have been glad to hear that recently the necessity of some such action in Oxford has been receiving the attention of certain members of the University. It appears to me, and I feel sure it will appear to others interested in the study of temperance, that the proposal to found a library in Oxford-dedicated to the memory of its distinguished son, Archbishop Temple, chairman of the first Lees and Raper Memorial Lecture-is one that should merit approval. Such a library, in addition to forming a home for all suitable publications and statistics on this subject that are or have been issued in this and other countries, would also be available for the use of the members of the University and others, and would naturally form a centre for the encouragement of the academic study of the question. Another excellent suggestion has been made in connexion with this movement, that one or two travelling scholarships should be created, in order to give members of the University the opportunity of studying the effect of temperance legislation in other countries, and thus be able to give to the world the opinion of the University as to the benefits, or otherwise, which these countries have derived from such legislation.

If the delivery of the eighth Lees and Raper Memorial Lecture in this ancient and honoured University town be in any measure helpful to this end, then your presence here to-night, and your practical interest, will not have been in vain. 